\title{
ADHERENCE TO THE AEROBICS EXERCISE PROGRAM IN WOMEN AGED 40 TO 65
}

\author{
Liběna Kováčová, Pavel Stejskal, Filip Neuls, Milan Elfmark
}

Faculty of Physical Culture, Palacký University, Olomouc, Czech Republic

Submitted in February, 2010

BACKGROUND: The analysis of exercise adherence belongs among the basic criteria for evaluation of the efficiency of intervention exercise programs.

OBJECTIVE: The aim of this study was to analyze the adherence of participants to the half year dance and step aerobics program.

METHODS: The experimental group consisted of 47 women aged 40 to 65 years old who exercised three times per week for a period of six months. The participant's attendance sheets and their answers to two questions from the checklist were used for the evaluation of their adherence to the workouts.

RESULTS: The mean value of the adherence of the whole group to the intervention exercise program was $70.43 \%$. Mean values of the group gradually decreased from $85.39 \%$ to $68.35 \%$ during the first four months of the intervention exercise program. In the last two months of the intervention, the adherence continued to decrease when the average values of their attendance were slightly under $60 \%$. Compared to other months, these differences were statistically and logically significant.

CONCLUSIONS: Reasons for different or possibly decreasing degrees of adherence to long lasting intervention exercise programs are mostly objective, e.g. health (55.17\%), family (13.70\%) and work (22.41\%). Other reasons (8.62\%) are based on psychological factors (motivational and personal characteristics), the offerings and attractiveness of the activities, which are closely associated to the current health status and movement experience of the individual. Even the group form of exercise does not guarantee a high rate of the participant's adherence.

Keywords: Lifestyle, physical activity, aerobics, intervention program, motivation.

\section{INTRODUCTION}

Our research is based on the well-known and respected theory of the beneficial influence of physical activity on health at every stage of development (Dishman \& Buckworth, 1996; Dishman, Washburn, \& Heath, 2004; Haskell et al., 2007; Hendl \& Dobrý, 2008; Nelson et al., 2007). In particular, productive and post-productive age is characterized by the body's gradual aging and the rising need and significance of physical activity to preserve health, and physical efficiency to prolong active age (Šimonek, 2000). It is not only the natural aging process which decreases the quality of life. There are also other factors, including urbanization and increased technological development, which significantly reduce the volume and intensity of natural physical activity possibly resulting in health disorders (Hendl \& Dobrý, 2008; Stejskal, 2005).

Epidemiological studies bring us evidence that only a small portion of inhabitants are physically active in their leisure time. When considering Czech inhabitants, a basic study by Frömel, Bauman et al. (2006) confirms trends of decreasing vigorous physical activity and involvement in organized forms of physical activity with age.
The quality of women's life is mostly threatened in middle and older adult age (Slattery et al., 2006) when the health risks associated with menopause occur (Klebanoff, Miller, \& Fernhall, 1998). In this period, women often make a serious evaluation of their personal qualities and previous way of life (Štěrbová et al., 2008). Regular physical activity may be one of the ways of maintaining or improving one's physical and psychological condition and thus, coping with the syndromes typical of this period of a woman's life. Physical activity makes it possible to develop social contacts and friendly relationships; thereby it extends social-cultural dimensions. Group forms of exercising can, above all, not only bring a feeling of satisfaction, but also encourage the participants to achieve better performance and develop adherence to a regular physical activity. Spink and Carron (1992) denote group cohesion as a key factor determining a degree of adherence in most adults and directly influencing adherence of women to group forms of exercise.

The World Health Organization (WHO) recommends that exercise have an endurance pattern and account for $50-60 \%$ of one's total physical activity (in Šimonek, 2000). Endurance exercises affect a substantial part of the major muscular groups. A higher intensity of shorter 
term endurance exercises may compensate for low intensity physical activity lasting for several hours (Stejskal, 2004). Both, too high or too low intensities decrease the efficiency of exercises and do not provide health benefits. Therefore, it is necessary to prescribe an optimal physical activity program with respect to age, gender, health, physical fitness, etc.

Research confirms that aerobics as a form of endurance exercise belongs to the most preferred physical activities, especially in women (Nieman, 1992). In concordance with this fact, Bowyer (1996) or Frömel, Novosad and Svozil (1999) point out that especially the female population gives preference to esthetically oriented physical activities, such as aerobics.

From the biomedical point of view, moderate-intensity aerobic exercise programs of 6-12 months induce only a modest reduction in weight or waist circumference in overweight and obese women. However, isolated aerobic exercise provides some benefits to blood pressure and lipid levels and may still be an effective weight loss therapy in conjunction with diets (Thorogood et al., 2011).

An efficient solution seems to be adequate intervention exercise programs designed to increase the proportion of physical activity in an individual's lifestyle. The efficiency of an intervention exercise program is dependent on many factors - on the exercise content (offering) of the program, the volume and intensity of the exercise, the participants' age and health status, their motivation, their feeling of satisfaction, etc.

On the other hand, research also underlines a problem of adherence to physical activity programs and physical activity itself. Almost 50\% of individuals, who start their participation in some physical activity program, terminate within 2 to 6 months (Dishman, 1988). Thus, worldwide attempts to support drafts and realization of adequate intervention programs exist with objectives not only to increase the physical activity level in anyone's respective personal lifestyle but also to motivate individuals to undertake long lasting behavioral changes supporting permanent adherence to regular physical activity.

Factors influencing anyone's adherence to physical activity are recognized in a variety of theories, e.g. a theory accenting the setting and definition of goals, estimates of progress and planning, increases in resistance and stamina (Annesi, 2004). Bandura's social-cognitive theory (Bandura, 2001) emphasizes self efficacy and the awaited result in fulfilling set aims. However, in the study of Opdenacker, de Bourdeaudhuij, Vanden Auweele and Boen (2009), the mechanisms proposed by the social-cognitive theory and transtheoretical model could not explain the positive effect of the intervention on physical activity. Identifying the working components of an intervention attempt remains a challenging and necessary step in the development of effective lowcost and high reach physical activity intervention.

A motivational factor in the area of lifestyle is a subjective self perception which significantly contributes to increasing quality of life indicators (Štěrbová, 2008). Thus, the majority of studies assessing adherence to physical activity analyze adherence from the psychological point of view and focus on motivational orientation and the motivational climate (Stornes, 2001).

\section{AIMS}

The aim of this study was to analyze the adherence of women to an intervention program of aerobics exercise. Exercise adherence is one of the basic criteria for the evaluation of a program's efficiency.

\section{METHODS}

\section{Subjects}

All participants were involved on a voluntary basis and provided a written agreement with conditions of the intervention program. The conditions were presented during the first information meeting of potential participants and the organization team of the intervention study. The sample consisted of 47 women aged between 40-65 years $(M=47.32 ; S D=5.38)$ with a mean body mass index of $26.48 \mathrm{~kg} \times \mathrm{m}^{-2}\left(S D=4.18 \mathrm{~kg} \times \mathrm{m}^{-2}\right)$. Entrance criteria were: an interest in exercise, a sedentary lifestyle, the appropriate age category, health status allowing for participation in the exercise program as much and as often as possible and willingness to undergo psychological examination before and after the intervention program. The group was divided into two subgroups according to the type of aerobics, subgroup A ( $n=24$; dance aerobics) and subgroup $B(n=23$, step aerobics $)$.

\section{The intervention exercise program}

The intervention exercise program was held from September 2005 to March 2006, lasted six months and was carried out as group exercise with music under the supervision of an expert instructor.

Dance aerobics was based on walking and step variations, knee bends, lunges (low impact aerobics; LIA), running, skipping and hopping (high impact aerobics; HIA) and their combination (low high impact aerobics). This exercise was accompanied by controlled movements of the arms.

Step aerobics was based on stepping up and stepping down with the use of a $10 \mathrm{~cm}$ or $13 \mathrm{~cm}$ high step aerobic platform, combined with step variations on the platform and around the platform as well. Each movement was planned and put together in order to create a composi- 
tion (choreography), which was modified after a month. The choreography followed methodology and learning techniques called learning patterns (Bolton, 1996).

The intervention exercise program was based on three workouts of aerobics per week (subgroup A - Monday, Wednesday, Friday; subgroup B - Tuesday, Thursday, Sunday) for 6 months. The total number of training lessons was 81 (100\%). Each workout lasted 60 minutes and consisted of an initial part (warming up, pre-stretching), main part (aerobics), bodybuilding and a final part (cooling down, deep stretching, relaxing). When summarized, the initial part and the main part lasted 40-45 minutes, whereas the other parts took 15 minutes.

The intensity of the exercise was also based on the tempo of the music (beats per minute; BPM), which was different in every part of the unit and according to the type of aerobics (LIA: 130-145 BPM; HIA: 150-160 BPM; step aerobics: 125-135 BPM). The tempo of the music was slower at the beginning, then it was gradually accelerated (on average, the tempo of the music was 135-142 BPM at the end).

\section{Evaluation of adherence}

For the evaluation of the women's adherence to the training units and the intervention exercise program itself, the participant's attendance sheets and their answers to two questions from the checklist were used. The checklist was developed especially for the research project of the Faculty of Physical Culture at Palacký University (project no. 6198959221), which includes also this study.

Both questions referred to adherence and factors influencing its level (question no. 1 "Did you participate in the last exercise?" and question no. 2 "If not, what was the reason?"). The analysis of the factors influencing the level of adherence of the women to the aerobics exercise program was based on the results of psychological examinations focused on performance motivation and the life satisfaction of women, self monitoring, reaching the chosen aims and the self-perception of physical and mental fitness referred to as intentional physical activity. These examinations were carried out by a team of psychologists at the Faculty of Physical Culture, Palacký University in Olomouc via the questionnaire method (Questionnaire of performance motivation, Questionnaire of life satisfaction; Stěrbová et al., 2008).

\section{Statistical methods}

Statistica 8.0 software was used for the data analysis of the women's attendance sheets. Basic statistical characteristics were calculated (mean, standard deviation, minimum value, maximum value, percent values, etc.) for each subgroup for each month and day.

To evaluate the whole sample according to the volume of exercise without differentiating groups into subgroups according to the aerobics type, the method of cluster analysis was used. This method divided the sample into three new subgroups. Input parameters were in attendance in particular months and the evaluation method was the $\mathrm{K}$ - means method.

The comparison of the subgroups A and B according to the type of aerobics in particular months and days was carried out by means of the one way analysis of variance for repeated measurement (ANOVA). Fischer's LSD test was used as a post hoc test. Logical significance was expressed by the coefficient $\eta^{2}$. Answers to question no. 2 from the checklist are presented in the form of percent values. The level of statistical significance was set to $\mathrm{p}<0.05$.

\section{RESULTS}

None of the participants from the sample $(n=47)$ showed $100 \%$ adherence during the whole intervention period. To evaluate and compare the intra-sample adherence regardless of the type of aerobics, the sample was divided into three subgroups by cluster analysis. The first subgroup consisted of 22 women, who attended the highest number of training units $(83.7 \pm 7.9 \%)$ and had the least decreasing tendency of attendance during the whole intervention exercise program. The third subgroup consisted of 7 women, who attended the lowest number of training units $(43.1 \pm 14.0 \%)$ and had the highest decreasing tendency of exercise attendance during the six month period. The second subgroup consisted of 18 women whose values of their volume of exercising were between both accumulation extremes and who had moderate decreases in exercise attendance (Fig. 2).

TABLE 1 displays the fact that the average value of the adherence of the whole group to the intervention exercise program was $70.43 \%$. The average values of the group were gradually decreasing from $85.39 \%$ to $68.35 \%$ during the first four months of the intervention exercise program (October, November, December and January). During the last two months (February, March) the average value of their attendance was slightly under $60 \%$ and this value was statistically and logically significant when compared to the other months.

As showed in Fig. 1, subgroup A (dance aerobics) has higher mean values of attendance when compared to subgroup B (step aerobics) in most months of the intervention exercise program. However, only in the fourth and fifth month of the intervention exercise program (January, February), do the values of the LSD test show statistically significant differences $(p=0.01)$. The decreasing tendency of their attendance can be seen in both subgroups where a statistically significant decrease begins already during the third month $(p=0.01)$ of the 
TABLE 1

Percent values of the adherence of women to the intervention exercise program according to subgroups, months and days

\begin{tabular}{|c|c|c|c|c|c|c|c|}
\hline Effect & Factor & $\mathbf{N}$ & M\% & SD\% & $\mathbf{F}$ & $\mathbf{p}$ & $\eta^{2}$ \\
\hline Total & & 146 & 70.43 & 15.94 & & & \\
\hline Subgroup & $\mathrm{A}$ & 73 & 72.36 & 14.54 & \multirow{2}{*}{5.71} & \multirow{2}{*}{0.02} & \multirow{2}{*}{0.05} \\
\hline Subgroup & B & 73 & 68.49 & 17.11 & & & \\
\hline Day & 1 & 50 & 75.92 & 13.62 & \multirow{3}{*}{12.06} & \multirow{3}{*}{$<0.01$} & \multirow{3}{*}{0.18} \\
\hline Day & 2 & 49 & 70.10 & 16.46 & & & \\
\hline Day & 3 & 47 & 64.94 & 16.04 & & & \\
\hline Month & 1 & 25 & 85.39 & 7.49 & \multirow{6}{*}{37.72} & \multirow{6}{*}{$<0.01$} & \multirow{6}{*}{0.63} \\
\hline Month & 2 & 25 & 84.57 & 7.54 & & & \\
\hline Month & 3 & 19 & 69.43 & 18.29 & & & \\
\hline Month & 4 & 26 & 68.35 & 11.27 & & & \\
\hline Month & 5 & 24 & 56.31 & 13.00 & & & \\
\hline Month & 6 & 27 & 58.73 & 8.41 & & & \\
\hline
\end{tabular}

Legend: $\eta^{2}$ - logical significance coefficient, $\mathrm{N}$ - number of training units, $\mathrm{M} \%$ - mean (percent), SD\% - standard deviation (percent), A - dance aerobics $(n=24), B-$ step aerobics $(n=23)$

Fig. 1

The adherence of women in particular months and subgroups divided according to the type of aerobics (A dance, $n=24 ; B-$ step, $n=23$ )

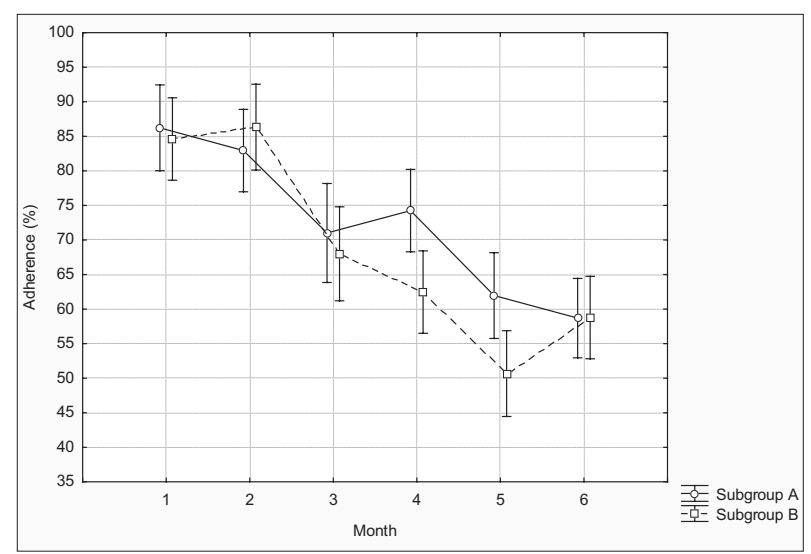

intervention program and peaks negatively in the last month $(p<0.01)$. The same progress of their attendance can be recognized also in subgroup B where the lowest attendance is in the next to last month $(p=0.01)$.

The mean value of the attendance during six months was $72.36 \%$ in subgroup A and $68.49 \%$ in subgroup B (TABLE 1). This difference is statistically significant $(p=0.02)$ but the coefficient $\eta^{2}$ denotes only a low effect.

The decreasing tendency of the attendance within the sample is recognizable also on a weekly basis on particular exercise days. TABLE 1 displays the fact that the highest attendance was always at the beginning of
Fig. 2

Adherence of women in particular months within the three subgroups $\left(\mathrm{n}_{1}=22, \mathrm{n}_{2}=18, \mathrm{n}_{3}=7\right)$ divided according to the volume of exercise (see also Stejskal et al., 2007)

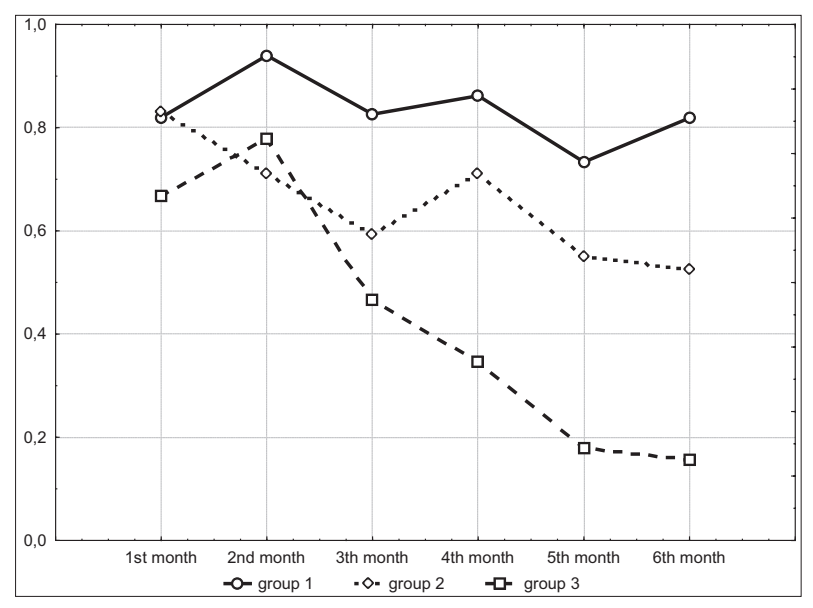

the week and decreased towards the weekend. The difference between particular days was statistically and logically significant $\left(p<0.01, \eta^{2}=0.18\right)$. This tendency can be seen in Fig. 3 which displays and graphically compares attendance on the days of exercise within the subgroups divided according to the type of aerobics.

The results of analysing question no. 1 ("Did you participate in the last exercise?") and question no. 2 ("If not, what was the reason?") of the checklist yielded the following most frequently stated reasons for absence: health related reasons $(55.17 \%)$, work related reasons $(22.41 \%)$, family related reasons $(13.70 \%)$ and others $(8.62 \%)$. 
Fig. 3

Adherence of women in particular days of exercise in subgroups divided according to the type of aerobics (A dance, $n=24$; $B$ - step, $n=23$ )

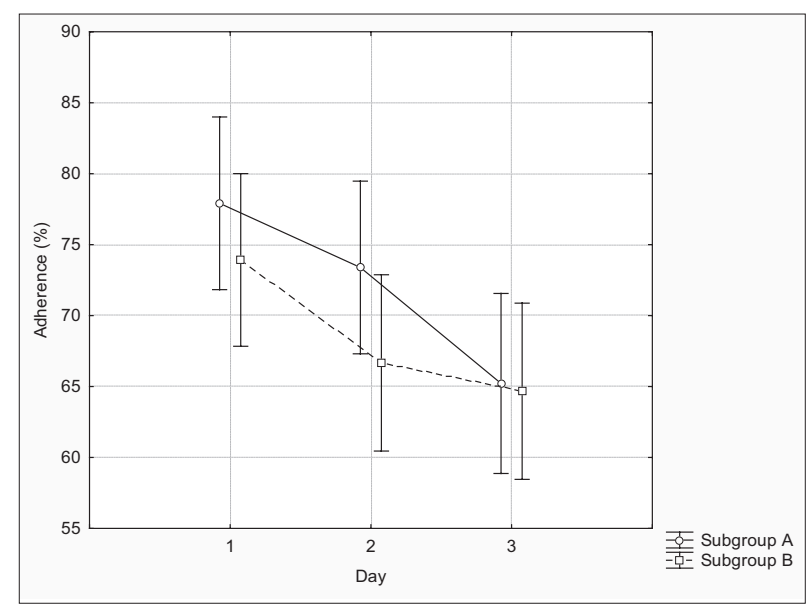

\section{DISCUSSION}

Song, June, Kim and Jeon (2004) confirm that the six-month program with dance aerobic activity has a positive motivational effect, not only on adherence but also on behavioral changes according to principles of a healthy lifestyle at later adult age. In other study, Cox et al. (2003) observe that 6 months of center based exercise can promote short term adherence and energy expenditure. In the presented study, analyses of the adherence of women to the six month physical activity program of aerobics with music indicate that the adherence of women to regular physical activity is influenced by many factors. Štěrbová et al. (2008) claims that women have had positive experience with the intervention exercise program and give a positive evaluation to the influence of group exercises.

Spink and Carron (1992) assume that the key factor determining the extent of adherence to exercise is primarily group cohesion (the level and intensity of mutual relationships, integral self perception within the group). A high level of cohesion increases the enjoyment of the group members, participation in a common task or performance, self satisfaction, and brings additional psychological benefits. According to Irvin et al. (2004), a significant predictor of the exercise adherence in women is a history of participating in any sports or recreational physical activity.

We found out that the frequency of attendance at workouts during the program decreased in some women more than in others. Instructors did not influence this spontaneous difference between the women's adherence on purpose, but the given factor significantly influenced the results of the whole intervention exercise program (Jakubec et al., 2006; Přidalová et al., 2007; Stejskal et al., 2007).
We suppose that the decreasing tendency to attend over a given period of time may be a signal of the decreasing level of the women's motivation to take exercise. So the reasons for different adherence may be identified in the motivational orientation of individuals and some specific personality features - as, for example, the ability to exert oneself, one's resolution, diligence, tendency to stick to an activity and accomplish a set goal. The motivational process is also an evaluating process and motivation corresponds to goals relevant to the individual. From this point of view, individual satisfaction with reaching relevant goals leading to regular exercising played a significant role in the results of the women involved in the program. On the other hand, especially external motivation oriented to body image and mass-media supported ideals can lead to involvement in physical activity and exercise programs, but this involvement will probably not be persistent, especially in middle aged women (Annesi, 2004; Biddle \& Mutrie, 1991; Ryan et al., 1997). Thus, unrealistic expectations can become demotivating (Roberts, 2001).

Štěrbová et al. (2008) also perceive reasons for quantitative differences in psychological factors (as, for example, the degree of the initial motivation, fulfilling individually determined goals, the ability to organize one's family duties and leisure time, ambition, endurance, self confidence, etc.) and in objective reasons (as, for example, health, work and family problems, etc.). These opinions correspond to our results based on an analysis of the checklists.

A team of psychologists from the Faculty of Physical Culture at Palacký University carried out detailed analyses of the reasons for the women's different adherence to exercises before the beginning of the whole intervention exercise program. The women's motivation to achieve a certain performance level and their life satisfaction were examined.

The function of performance motivation refers to increased perceived self esteem or experiencing pride in performance. Biddle (1997) and Roberts (2001) confirm that people are motivated to do activities which allow them to have positive feelings of competence and efficacy.

According to Štěrbová et al. (2008), six dimensions of personality (belief in success, courage, self reliance, internalization, compensational effort and endurance) contribute to the sense of life satisfaction in women in middle and advanced adult age who take exercise regularly. These personal dimensions related to performance emphasize the significance of individual resources as, for example, time, talent or effort, which make achievement of the determined goal possible.

In the examined sample, the relationship between personal dimensions and life satisfaction was statistically significant in components of life satisfaction, such as health, children, leisure, sexuality, and friends. A higher 
level of life satisfaction is a good precondition for adherence to regular physical activity.

Determinants of adherence to physical activity and exercise are as follows: personal (history of participation in exercise programs, knowledge of and belief in health benefits of exercising, self motivation, age, education level, health and fitness, mood), physiological (body weight, cardiovascular diseases, injuries, general health status), situational (social support, suitable opportunity, lack of time, atmosphere, cost, family and personal problems, stereotype), behavior (bad habits, lifestyle, type of behavior) and program (group or individual exercise, exercise intensity, qualities of instructor, physical activity choice). Possibilities to choose an appropriate type of physical activity and a preferred type of exercise can be very important for adherence because it can also strongly depend on enjoyment of the concrete form of exercise (White, Ransdell, Vener, \& Flor, 2005).

We found out that the movement content of the intervention program (in this case - aerobics) is the next reason for different adherence. The analysis of exercise intensity showed that the duration of the participants' exercise in the recommended HR zone was highly variable. The average duration of exercise in the recommended range of HR was $18.68 \pm 6.40$ minutes (Kováčová, Stejskal, Neuls, Jakubec, \& Elfmark, 2007). With respect to the total duration of the training unit, the length of the average duration of exercise in the recommended HR zone was relatively low. This fact may be explained by the participants' problems with technique, rhythm and coordination, as well as by didactic limits connected with the method of gradual drilling of the choreography used. In addition, the movement content of aerobics should be in harmony with music and not everybody has the corresponding predisposition for this skill. The majority of women in the examined sample did not have any experience with aerobics, thus, it is possible that they did not enjoy this type of exercise.

Another problem with the duration of exercise in the recommended HR zone might be in the group exercising. In the group, the exercise intensity should be adjusted to the participants with a lower degree of fitness, which may not be enough for participants with a higher degree of fitness.

Although the benefits of the group form of exercise are generally well-known, some authors assume that individually tailored exercise intervention can be the most accessible to the sedentary population of women in middle and older adult age (Findorff, Wyman, \& Gross, 2009). To facilitate the increased physical activity level in women of middle and older adult age, comprehensive, cognitive-behavioral, and gender-tailored physical activity intervention is emphasized (Hanlon, Morris, \& Nabbs, 2010; Segar, Jayaratne, Hanlon, \& Richardson, 2002).
It remains unanswered which minimum level of exercise adherence can be acceptable so that the intervention program could be denoted as being successful although the effectiveness of the intervention programs themselves in increasing physical activity had been reviewed systematically by Kahn et al. (2002). However, it is possible to expect that successful exercise intervention has the potential to change physical activity behavior on a long term basis and to increase the physical activity of participants to a level corresponding with generally respected physical activity recommendations (e.g. to perform moderate physical activity for at least $30 \mathrm{minu}-$ tes five times a week or vigorous physical activity for at least 20 minutes three times a week; U.S. Department of Health and Human Services, 2000).

\section{CONCLUSIONS}

Women's adherence to exercises is one of the basic criteria for the evaluation of the efficiency of an intervention exercise program. Reasons for the different or possibly decreasing adherence to long lasting intervention exercise programs are mainly in psychological factors (motivational and personal characteristics) and objective reasons (health, family, work, etc.). The offer and attractiveness of the activities are also important and closely connected with the current health and movement experience of the individual. Even the group form of exercising does not guarantee a high rate of the participant's adherence.

\section{ACKNOWLEDGEMENT}

The study has been supported by the research grant from the Ministry of Education, Youth and Sports of the Czech Republic (No. MSM 6198959221) "Physical Activity and Inactivity of the Inhabitants of the Czech Republic in the Context of Behavioral Changes”.

\section{REFERENCES}

Annesi, J. J. (2004). Relationship of percieved health and appearance improvement, and self motivation, with adherence to exercise in previously sedentary women. European Journal of Sport Science, 4, 1-13.

Bandura, A. (2001). Social cognitive theory: An agentive perspective. Annual Review of Psychology, 52, $1-26$.

Biddle, S. J. H. (1997). Cognitive theories of motivation and the physical self. In K. R. Fox (Ed.), The physical self: From motivation to well-being (pp. 59-82). Champaign, IL: Human Kinetics. 
Biddle, S. J. H., \& Mutrie, N. (1991). The psychology of physical activity. London: Springer-Verlag.

Bolton, A. (1996). Aerobics instructor course. Sydney: Network for Fitness Professionals.

Bowyer, G. R. (1996). Student perceptions of physical education. Journal of Physical Education, Recreation and Dance, 67(1), 23-26.

Cox, K. L., Burke, V., Gorely, T. J., Beilin, L. J., \& Puddey, I. B. (2003). Controlled comparison of retention and adherence in home vs center initiated exercise interventions in women ages 40-65 years: The S.W.E.A.T. Study (Sedentary Women Exercise Adherence Trial). Preventive Medicine, 36, 17-29.

Dishman, R. K. (1988). Exercise adherence: Its impact on public health. Champaign, IL: Human Kinetics.

Dishman, R. K., \& Buckworth, J. (1996). Increasing physical activity: A quantitative synthesis. Medicine and Science in Sports and Exercise, 28, 706-719.

Dishman, R. K., Washburn, R. A., \& Heath, G. W. (2004). Physical activity epidemiology. Champaign, IL: Human Kinetics.

Findorff, M. J., Wyman, J. F., \& Gross, C. R. (2009). Predictors of long term exercise adherence in a community based sample of older women. Journal of $\mathrm{Wo}$ men's Health, 11, 1769-1776.

Frömel, K., Novosad, J., \& Svozil, Z. (1999). Pohybová aktivita a sportovní zájmy mládeže. Olomouc: Univerzita Palackého.

Frömel, K., Bauman, A. et al. (2006). Intenzita a objem pohybové aktivity 15-69leté populace České republiky. Česká kinantropologie, 10(1), 13-28.

Hanlon, C., Morris, T., \& Nabbs, S. (2010). Establishing a successful physical activity program to recruit and retain women. Sport Management Review, 13, 269-282.

Haskell, W. L. et al. (2007). Physical activity and public health. Updated recommendation for adults from the American College of Sports Medicine and the American Heart Association. Circulation, 116, 1081-1093.

Hendl, J., \& Dobrý, L. (2008). Teorie a modely intervenčních programů pro zvýšení pohybové aktivnosti. Česká kinantropologie, 12(3), 26-33.

Irwin, M. L., Tworoger, S. S., Yasui, Y., Rajan, B., McVarish, L., LaCroix, K., Ulrich, C. M., Bowen, D., Schwartz, R. S., Potter, J. D., \& McTiernan, A. (2004). Influence of demographic, physiological, and psychosocial variables on adherence to a yearlong moderate intensity exercise trial in postmenopausal women. Preventive Medicine, 39, 1080-1086.

Jakubec, A., Stejskal, P., Kováčová, L., Řehová, I., Petr, M., \& Přidalová, M. (2006). Změny spektrální analýzy variability srdeční frekvence a vybraných funkčních parametrů po šestiměsíčním cvičení aerobiku u 40-60letých žen [Abstract]. In D. Hamar (Ed.), Pohybová aktivita v zdraví a chorobe: 3. više- grádsky kongres telovýchovného lekárstva (pp. 14-15). Bratislava: Slovenská spoločnost telovýchovného lekárstva.

Jakubec, A., Stejskal, P., Kováčová, L., Elfmark, M., Řehová, I., Botek, M., \& Petr, M. (2008). Changes in heart rate variability after a six month long aerobic dance or step dance program in women $40-65$ years old: The influence of different degrees, intensity and initial levels. Acta Universitatis Palackianae Olomucensis. Gymnica, 38(2), 35-44.

Kahn, E. B., Ramsey, L. T., Brownson, R. C., Heath, G. W., Howze, E. H., Powell, K. E., Stone, E. J., Rajab, M. W., Corso, P., \& the Task Force on Community Preventive Services (2002). The effectiveness of interventions to increase physical activity: A systematic review. American Journal of Preventive Medicine, 22, 73-107.

Klebanoff, R., Miller, V. T., \& Fernhall, B. (1998). Effects of exercise and estrogen therapy on lipid profiles of postmenopausal women. Medicine and Science in Sports and Exercise, 30, 1028-1034.

Kováčová, L., Stejskal, P., Neuls, F., Jakubec, A., \& Elfmark, M. (2007). Půlroční program dance a step aerobiku u žen ve věku od 40 do 65 let. In A. Marousek (Ed.), Konference plná barev: Mezinárodní studentská védecká konference v oboru kinantropologie (pp. 62-66). Olomouc: Univerzita Palackého.

Nelson, M. E. et al. (2007). Physical activity and public health in older adults: Recommendation from the American College of Sports Medicine and the American Heart Association. Medicine and Science in Sports and Exercise, 39, 1435-1445.

Opdenacker, J., de Bourdeaudhuij, I., Vanden Auweele, Y., \& Boen, F. (2009). Psychosocial mediators of a lifestyle physical activity intervention in women. Psychology of Sport and Exercise, 10, 595-601.

Přidalová, M., Dostálová, I., Kováčová, L., Neuls, F., Janura, M., Elfmark, M., \& Švec, J. (2007). The changes of selected somatic characteristics by the effect of organized physical activity of aerobic character. In Auksologia a promocja zdrowia (pp. 187-195). Kielce: Kieleckie Towarzystwo Naukowe.

Roberts, G. C. (2001). Advances in motivation in sport and exercise. Champaign, IL: Human Kinetics.

Ryan, R. M. et al. (1997). Intrinsic motivation and exercise adherence. International Journal of Sport Psychology, 28, 335-354.

Segar, M., Jayaratne, T., Hanlon, J., \& Richardson, C. R. (2002). Fitting fitness into women's lives: Effects of a gender tailored physical activity intervention. Women's Health Issues, 12(6), 338-347.

Slattery, M. L., Sweeney, C., Edwards, S., Herrick, J., Murtaugh, M., Baumgartner, K., Guiliano, A., \& Byers, T. (2006). Physical activity patterns and obesity in Hispanic and non Hispanic white women. Medicine and Science in Sports and Exercise, 38, 33-41. 
Song, R., June, K. J., Kim, C. G., \& Jeon, M. Y. (2004). Comparison of motivation, health behaviors, and functional status among elders in residential homes in Korea. Public Health Nursing, 21, 361-371.

Spink, K. S., \& Carron, A. C. (1992). Group cohesion and adherence in exercise classes. Journal of Sport and Exercise Psychology, 14, 78-86.

Stejskal, P. (2004). Proč a jak se zdravě hýbat. Presstempus.

Stejskal, P., Jakubec, A., Kováčová, L., Elfmark, M., Řehová, I., Petr, M., \& Cypryan, L. (2007). Vliv rozdílné adherence $\mathrm{k}$ půlročnímu programu aerobiku na aerobní zdatnost. Medicina Sportiva Bohemica et Slovaca, 16(1), 14-25.

Stornes, T. (2001). Sportspersonship in elite sports: On the effects of personal and envirommental factors on the display of sportspersonship among elite male handball players. European Education Review, 7, 281-301.

Šimonek, J. (2000). Pohybová aktivita v živote súčasného človeka. In Pohybová aktivita žien (pp. 23-65). Bratislava: Slovenský olympijský výbor.

Štěrbová, D., Hrubá, R., Harvanová, J., Elfmark, M., \& Otipková, D. (2008). Faktory adherence k pohybové aktivitě žen ve věku 40-65 let. Československá psychologie, 52(4), 378-387.

Thorogood, A., Mottillo, S., Shimony, A., Filion, K. B., Joseph, L., Genest, J., Pilote, L., Poirier, P., Schiffrin, E. L., \& Eisenberg, M. J. (2011). Isolated aerobic exercise and weight loss: A systematic review and meta analysis of randomized controlled trials. The American Journal of Medicine, 124, 747-755.

White, J. L., Ransdell, L. B., Vener, J., \& Flor, J. A. (2005). Factors related to physical activity adherence in women: Review and suggestions for future research. Women's Health, 41, 123-148.

U.S. Department of Health and Human Services (2000). Healthy People 2010 (Vols. 1 \& 2). Washington, DC: U.S. Government Printing Office.

\section{ADHERENCE KE CVIČEBNÍMU PROGRAMU AEROBIKU U ŽEN VE VĚKU 40 AŽ 65 LET}

(Souhrn anglického textu)

VÝCHODISKA: Jedním ze základních kritérií hodnocení efektivity dlouhodobých intervenčních pohybových programů je analýza adherence účastníků ke cvičení.

CÍLE: Cílem této studie bylo analyzovat adherenci souboru žen k šestiměsíčnímu programu dance aerobiku a step aerobiku.

METODIKA: Skupinu tvořilo 47 žen ve věku od 40 do 65 let (47,32 $\pm 5,38$ let), které cvičily třikrát týdně po dobu 6 měsíců. $\mathrm{K}$ analýze adherence byla použita meto- da záznamového (prezenčního) listu účasti frekventantek a odpovědi na dvě otázky z anketního listu.

VÝSLEDKY: Průměrná hodnota adherence celého souboru k pohybovému intervenčnímu programu byla 70,43 \% . První čtyři měsíce pohybového intervenčního programu průměrné hodnoty souboru postupně klesaly od $85,39 \%$ do $68,35 \%$ a poslední dva měsíce se průměry docházky stále snižovaly až pod hranici $60 \%$, přičemž v porovnání s ostatními měsíci byly tyto rozdíly statisticky i věcně významné.

ZÁVĚRY: Příčiny rozdílné, popř. klesající adherence žen $\mathrm{k}$ intervenčnímu pohybovému programu jsou hlavně v objektivních důvodech jako nemoc (55,17 \%), péče o rodinu $(13,70 \%)$ a zaměstnání $(22,41 \%)$. Dalšími důvody $(8,62 \%)$ jsou psychologické faktory (motivační a osobnostní charakteristiky), výběr a atraktivita pohybové aktivity, která úzce souvisí s aktuálním zdravotním stavem, a pohybová zkušenost jednotlivce, související s intenzitou cvičení. Ani skupinová forma cvičení nemusí být zárukou vysoké míry adherence k pohybovému programu.

Klíčová slova: životní styl, pohybová aktivita, aerobik, intervenční program, motivace.

\section{PaedDr. Liběna Kováčová}

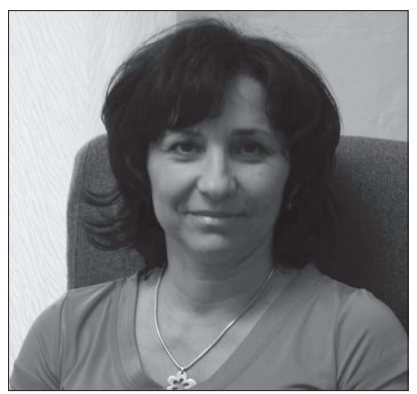

Palacký University

Faculty of Physical Culture tř. Míru 115

77111 Olomouc

Czech Republic

\section{Education and previous work experience}

1979-1984 - Pedagogical Faculty, Palacký University Physical Education - Biology, Mgr.

1984-1987 - teacher at elementary school.

1987-1994 - Pedagogical Faculty, J. E. Purkyne University - Assistant Professor.

1990 - Pedagogical Faculty, J. E. Purkyne University PaedDr.

1994-present - Faculty of Physical Culture, Palacký University - Assistant Professor.

\section{First-line publications}

Kováčová, L. (2002). Aerobik. Tělesná výchova a sport mládeže, 68(1), 10-15.

Kováčová, L., Stejskal, P., Neuls, F., Jakubec, A., \& Elfmark, M. (2007). Půlroční program dance a step aerobiku u žen ve věku od 40 do 65 let. In A. Marousek (Ed.), Konference plná barev: Mezinárodní 
studentská védecká konference v oboru kinantropologie (pp. 62-66). Olomouc: Univerzita Palackého.

Kováčová, L., Stejskal, P., \& Elfmark, M. (2010). Subjektivní hodnocení intervenčního pohybového programu žen středního a pozdního věku. Medicina Sportiva Bohemica et Slovaca, 19(4), 226-229.

Stejskal, P., Jakubec, A., Kováčová, L., Elfmark, M., Řehová, I., Petr, M., \& Cipryan, L. (2007). Influence of different adherences to the six month aerobic dance or step dance on the aerobic fitness. Medicina Sportiva Bohemica et Slovaca, 16(1), 14-25.

Přidalová, M., Dostálová, I., Kováčová, L., Neuls, F., Janura, M., Elfmark, M. et al. (2007). The changes of selected somatic characteristics by the effect of organized physical activity of aerobic character. In Auksologia a promocja zdrowia (pp. 187-195). Kielce: Kieleckie Towarzystwo Naukowe.

Jakubec, A., Stejskal, P., Kováčová, L., Elfmark, M., Klimešová, I., Botek, M. et al. (2008). Changes in heart rate variability after a six month long aerobic dance or step dance programme in women 40-65 years old: The influence of different degrees, intensity and initial levels. Acta Universitatis Palackianae Olomucensis. Gymnica, 38(2), 35-44. 